\title{
ANALISIS KEMAMPUAN GURU DALAM MEMANFAATKAN MEDIA BEBASIS KOMPUTER PADA PEMBELAJARAN DI SEKOLAH DASAR
}

\author{
Adlin, SE., MM. \\ Politeknik Negeri Media Kreatif PSDD Makassar \\ andiadlin01@gmail.com
}

\begin{abstract}
Abstrak
Guru dalam menyampaikan materi memerlukan alat bantu perantara agar proses penyampaian materi lebih mudah dan tepat sasaran. Adapun cara tersebut yaitu dengan menggunakan media pembelajaran. Salah satu media pembelajaran yang dapat digunakan guru dalam pembelajaran yaitu media berbasis komputer. Tujuan dari penelitian ini adalah mengetahui kemampuan dan pengetahuan guru dalam menerapkan media pembelajaran berbasis komputer, kendala dan upaya yang dilakukan guru dalam menerapkan media tersebut. Jenis penelitian ini adalah penelitian deskriptif dengan pendekatan kualitatif. Penelitian ini dilaksanakan di Sekolah Dasar Nusaharapan Permai, Kelurahan Katimbang, Kecamatan Biringkanayya, Kota Makassar. Kemudian teknik pengumpulan datanya dengan menggunakan observasi, wawancara, dan dokumentasi. Hasil penelitian ini menggambarkan guru-guru sudah mampu menerapkan media berbasis komputer. Guru sudah terampil dalam memanfaatkan sarana teknologi dan mengembangkan materi menjadi produk media berbasis komputer yang menarik, dan mudah diaplikasikan dalam pembelajaran. Tidak ada hambatan yang berarti bagi guru dalam menerapkan pembelajaran berbasis komputer. Upaya yang dilakukan guru yaitu dengan pengembangan diri melalui pelatihan dan pemanfaatan sarana dan prasarana teknogi yang sudah disediakan oleh sekolah.
\end{abstract}

Kata Kunci: Media; Berbasis Komputer; Pembelajaran; Guru Sekolah Dasar

\section{PENDAHULUAN}

Belajar adalah suatu proses yang kompleks yang terjadi pada diri setiap individu sepanjang masa hidupnya. Proses belajar itu terjadi karena adanya interaksi antara seseorang dengan lingkungannya. Oleh karena itu belajar dapat terjadi di rumah, di sekolah, di tempat kerja, di masyarakat, di tempat ibadah dan di masyarakat, serta berlangsung denga cara apa saja, dari apa saja dan dari siapa saja. Bahkan kemampuan orang untuk belajar ini merupakan salah satu ciri penting yang membedakan manusia dengan makhluk lain Media pembelajaran merupakan salah satu komponen pembelajaran yang mempunyai peranan penting dalam proses pembelajaran. Media pembelajaran telah memerankan dirinya sebagai sumber belajar sehingga memungkinan terjadinya proses pembelajaran secara mandiri oleh peserta didik. Oleh karena itu tiap-tiap pendidik perlu mempelajari bagaimana menetapkan media pembelajaran agar dapat mengefektifkan pencapaian tujuan pembelajaran dalam proses belajar mengajar Salah satu hal yang harus dimiliki oleh pendidik agar seseorang pendidik mampu menjalankan tugasnya dengan profesional adalah kompetensi pendidik, yang mampu mengikuti perkembangan zaman sehingga tidak ketinggalan. yaitu mampu memanfaatkan media berbasis teknologi yang tersedia saat ini untuk memudahkan dalam pembelajaran.

Dalam proses belajar-mengajar kehadiran media mempunyai arti yang cukup penting. Media dapat mewakili apa yang kurang mampu guru ucapkan melalui kata-kata atau kalimat tertentu, bahkan keabstrakan bahan dapat dikonkretkan dengan kehadiran media pendidikan, dengan demikian anak didik lebih mudah mencerna materi pelajaran dari pada tanpa bantuan media pembelajaran, karena dalam kegiatan tersebut ketidakjelasan dan kerumitan bahan yang akan disampaikan kepada anak didik dapat disederhanakan dengan bantuan media. Dalam setiap proses pembelajaran masih sangat sedikit guru yang merancang atau mendesain media 
pembelajaran pada Silabus dan RPP, sehingga penggunaan media pembelajaran masih terkesan seadanya, saat ini masih banyak guru yang menggunakan media pembelajaran sederhana yang kurang menarik minat siswa dalam mengikuti pembelajaran. Banyak guru yang hanya mengandalkan buku paket sebagai media pembelajarannya sehingga mengakibatkan prestasi belajar rendah. Permasalahan pokok dan cukup mendasar adalah sejauh manakah kesiapan guru dalam penggunaan media pendidikan dan pengajaran disekolah untuk pembelajaran siswa secara optimal sesuai dengan tujuan pendidikan dan pengajaran.

Fakta di lapangan terkait perkembangan teknologi dapat meningkatkan kualitas sumber daya manusia jika diaplikasikan dengan baik dan cerdas. Keberadaan teknologi mengalami kemajuan yang luar biasa terutama jaringan informasi dan komunikasi dengan ditandai munculnya beragam peralatan teknologi informasi seperti handphone smartphone, komputer, maupun laptop serta perkembangan jaringan internet global. Perkembangan teknologi yang mengalami kemajuan berdampak positif bagi prestasi siswa terutama dalam kegiatan pembelajaran di kelas.

Dewasa ini sebagai bentuk imbas dan respon positif terkait perkembangan teknologi, pemerintah juga menggencarkan Kurikulum 2013 meskipun kurikulum terus mengalami perubahan seiring perkembangan teknologi. Sebagai respon positif itulah pemerintah memberikan fasilitas berupa buku guru maupun buku siswa yang mudah diakses secara online oleh guru-guru maupun siswa, Selain kemudahan dalam mengakses bahan ajar, guru-guru juga dituntut untuk lebih inovatif dan kreatif teruatama menyikapi kebijakan dalam menerapkan pembelajaran menggunakan media berbasis komputer yaitudengan cara guru melek teknologi. Guru harus mampu menerapkan, bahkan mampu mengembangkan inovasi media pembelajaran berbasis komputer.

Berdasarkan masalah pada hal ini maka dirumuskan masalah dengan bentuk pertanyaan sebagai berikut:

1. Bagaimana penyusunan program pembelajaran dengan menggunakan media komputer di Sekolah Dasar.
2. Bagaimana proses pembelajaran menggunakan media komputer di Sekolah Dasar.

3. Apa saja hambatan penggunan media komputer dalam pembelajaran?

Untuk menghindari perluasan masalah dalam hal ini dan untuk mempermudah pemahaman, maka peneliti membatasai masalah yang akan diangkat adalah:

1. Untuk mengetahui kemampuan guru dalam menyusun program pembelajaran dengan menggunakan media komputer.

2. Untuk mengetahui kemampuan guru dalam menggunakan media komputer pada pembelajaran.

3. Untuk mengetahui hambatan dalam penggunaan media komputer.

Maka dalam pembahasan kali ini, Kami mengadakan penelitian lebih jauh tentang halhal tersebut. Dari hasil penelitian kami harapkan adanya target luaran yang dapat diperoleh tidak hanya dari segi manfaat teori tetapi juga mampu memberikan manfaat praktik bagi sekolah, institusi atau lembaga yang menjadi objek penelitian.

\section{METODE}

Metodologi penelitian yang digunakan adalah metodologi penelitian kualitatif yaitu mengkaji perspektif partisipan dengan strategi-strategi yang bersifat interaktif dan fleksibel. Penelitian kualitatif ditujukan sosial dari sudut pandang partisipan. Penelitian kualitatif adalah penelitian yang digunakan untuk meneliti pada kondisi objek alamiah dimana peneliti merupakan instrumen kunci (sugiyono, 2008).

Dalam penelitian ini, dibutuhkan data yang akurat dan dapat dipertanggung jawabkan. Sebagaiusahauntukmemperoleh data yang sesuai dengan masalah yang dihadapi maka perlu adanya suatu metode yang tepat untuk mencapai tujuan serta manfaat dari penelitian tersebut. Beberapa metodologi penelitian dalam perancangan ini adalah sebagai berikut:

\subsection{Pengumpulan Data}

Merupakan metode yang digunakan peneliti, dalam melakukan analisis data dan menjadikan informasi yang akan digunakan 
untuk mengetahui dihadapi.

permasalahan yang

\subsection{Observasi}

Observasi dilakukan untuk mengumpulkan data tentang praktik pembelajaran yang dilakukan guru, dan kompetensi guru dalam menerapkan media berbasis computer.

\subsection{Studi Pustaka}

Merupakan pengumpulan bahan- bahan yang berkaitan dengan judul Penelitian melalui membaca buku-buku dari perpustakaan dan mencari manfaat referensi dari internet, dan sebagainya.

\section{HASIL DAN PEMBAHASAN}

Tren penggunaan Teknologi Informasi dan Komunikasi dalam dunia pendidikan semakin marak. Beberapa sekolah maupun perguruan tinggi telah mencangkan pengembangan Teknologi Informasi dan Komunikasi dalam pembelajaran bagi peserta didik sebagai jaminan mutu pendidikan. Proses kegiatan belajar mengajar sudah banyak menggunakan media laptop, komputer, LCD Projector, audio visual dan didukung dengan internet/hostspot area, perpustakaan digital (elibrary), buku digital (e-book), pembelajaran digital (elearning), yang dapat diakses bebas dengan komputer/ laptop peserta didik.

Berdasarkan hasil observsi yang dilakukan, peneliti menemukan bahwa tidak semua guru menggunakan media komputer dalam proses pembelajaran. Adapun yang menggunakan komputer untuk mengambil absensi siswa atau bahan ajar untuk guru pribadi, mempresentasikan materi melalui slide power point, menampilkan video yang berkaitan dengan materi dan untuk mengakses informasi melalui jaringan internet.

Menjadi guru kreatif, professional dan menyenangkan dituntut untuk memiliki kemampuan mengembangkan media dan evaluasi pembelajaran yang efektif. Hal ini sangat penting terutama untuk menciptakan iklim pembelajaran yang kondusif dan menyenangkan. Karena proses belajar mengajar merupakan interaksi yang dilakukan antara guru dan peserta didik dalam suatu pembelajaran untuk mewujudkan tujuan yang telah direncanakan dan ditetapkan. Untuk mencapai hal tersebut maka guru harus mengetahui bagaimana cara untuk menyusun program pembelajaran dengan menggunakan media komputer. Untuk menyusun program pembelajaran maka guru harus memiliki landasan penggunaan komputer sebagai media pembelajaran. Berdasarkan hasil penelitian tersebut, dapat diketahui hal-hal yang menjadi landasan penggunaan media komputer dalam proses pembelajaran. Dalam menyusun program pembelajaran dengan menggunakan media komputer, guru harus mengetahui cara menyusun media pembejaran tersebut. Seiring perkembangan teknologi yang semakin pesat ini maka guru biasa dengan mudah menemukan berbagai sumber bahan pelajaran yang ada di internet. Selain kemampuan guru untuk menyusun program pembelajaran, ada juga hal yang perlu di pertimbangkan guru ketika akan menggunakan computer sebagai media pembelajaran. Berdasarkan hasil penelitian bersama salah satu tenaga pengajar beliau mengatakan bahwa: Selain guru harus mengetahui cara menyusun program pembelajaran dengan media komputer, guru juga di tuntut untuk memiliki kemampuan dalam menggunakan media.

Telah terjadi perubahan peranan guru. Guru tidak lagi berperan sebagai satu- satunya sumber belajar (learning resources), akan tetapi guru lebih berperan sebagai pengelola pembelajaran (manager of instruction). Dalam posisi semacam ini, bisa terjadi guru dan siswa saling membelajarkan. Dengan demikian kalau sekarang ada guru yang menganggap dirinya paling pintar, paling menguasai sesuatu, pendapatnya paling benar dan peserta didik dianggap tidak tahu apa-apa adalah keliru. Bisa jadi, peserta didik sekarang lebih mengetahui suatu hal dari pada guru, karena peserta didik dapat mencari sumber informasi dan pengetahuan dari berbagai media.

Perkembangan Teknologi Informasi dan Komunikasi menuntut perubahan paradigma pendidikan konvesional yang memiliki ciri pendidikan yang berpusat pada guru (teacher centered). Pendidikan berbasis Teknologi Informasi dan Komunikasi menekankan pada pendidikan yang berpusat pada peserta didik 
dan penguasaan Teknologi Informasi dan Komunikasi.

Penggunaan laptop atau komputer pada proses pembelajaran tergantung pada kondisi yang sedang berlangsung pada proses pembelajaran tersebut. Berdasarkan hasil pengamatan peneliti, peneliti menemukan bahwa ada kelas yang memang guru haruskan untuk menggunakan laptop untuk penjelasan materi dan ada juga kelas yang tidak terlalu perlu menggunakan laptop untuk penjelasan materi.

Pada umunya strategi pembelajaran aktif dengan memanfaatkan Teknologi informasi dan Komunikasi pada roses pembelajaran yaitu dengan metode Presentasi. Dalam presentasi, seorang guru tida selalu harus berdiri di depan kelas memberikan pelajaran atau cenderung menggunakan metode ceramah, tetapi bisa menggunakan video, film, atau slide interaktif yang divisualisasikan melalui LCD projector.

Melalui penggunana Laptop dan LCD Proyektor maka media ini dapat menjadikan presentasi lebih menarik. Keberhasilan utama dalam menggunakan strategi aktif presentasi adalah presenternya atau guru. Media hanyalah sarana yang membantu agar presentasi lebih menarik. Adapun kunci keberhasilan dalam proses pembelajaran di kelas terdapat pada guru yang memegang kunci utama. Oleh karena itu, diperlukan strategi agar presentasi lebih menarik dan berhasil.

Ada beberapa hal juga yang harus dipertimbangkan guru dalam menggunakan media komputer, antara lain tujuan pembelajaran yang ingin di capai ketika menggunakan media, katersedian dan biaya yang dikeluarkan ketika menggunakan media, karakteristik siswa dalam memahami materi melalui audio visual serta kinestetik (mendengar, melihat, mempraktekan), kondisi siswa dan kondisi tempat belajar.

Hal ini sangat penting untuk mencapai keberhasilan dalam menggunakan media berbasis Teknologi Informasi dan Komunikasi. Untuk menggunakan media pembelajaran berbasis Teknologi Informasi dan Komunikasi maka diperlukan seorang guru yang memiliki kemampuan, antara lain guru harus memahami tentang perangkat keras dan perangkat lunak yang ada pada komputer. Guru harus memahami cara untuk mengoperasionalkan yaitu harus tahu cara menghidupkan komputer sesuai dengan prosedur yang benar. Guru harus bisa mengelola data serta menggunakan komputer untuk keperluan proses pembelajaran dan guru harus tahu cara untuk menutup pembelajaran dan mematikan komputer sesuai dengan prosedur yang benar. Hal ini sesuai dengan teori yang kemukakan oleh Munir, beliau mengatakan bahwa ada beberapa keterampilan yang harus dimiliki seorang guru dalam menggunakan media komputer, antara lain:

1. Pengajar harus mengetaui cara mengoperasikan komputer yang digunakannya,

2. Pengajar harus memiliki pengetahuan tentang pemilihan software yang sesuai untuk pembelajaran,

3. Pengejar harus mengetaui cara melaksanakan proses pembelajaran melalui komputer dengan software yang digunakannya.

4. Pengajar harus memahami perbedaan perannya di dalam pembelajaran yang menggunakan media komputer dibandingkan dengan pembelajaran secara konvensional.

5. Pengajar harus mengetaui peran dan manfaat komputer yang dapat membantunya dalam proses pembelajaran.

6. Pengajar harus peka terhadap perkembangan teknologi pembelajaran terkini untuk memperluas wacana dan wawasan.

\section{SIMPULAN DAN SARAN}

\subsection{Kesimpulan}

Berdasarkan analisis pada pembahasan menyimpulkan bahwa ntuk mengintegrasikan pembelajaran berbasis teknologi infomasi dan komunikasi pada mata pelajaran, ada kemampuan yang dimiliki guru yaitu kemampuan dalam mengoperasikan komputer dan memilih software yang sesuai untuk pembelajaran. hal ini diperlukan agar guru bisa menyusun program pembelajaran dengan membuat materi pelajaran berdasarkan silabus dan rencana pembelajaran, landasan penggunaan media, peran teknologi infomasi dan komunikasi dalam pembelajaran dan tujuan penggunaan media komputer serta 
memanfaatkan fasilitas teknologi infomasi dan komunikasi yang telah disediakan oleh pihak sekolah. Dalam proses pembelajaran dengan menggunakan media komputer, ada beberapa kemampuan yang dimiliki guru yaitu memahami perbedaan peran antara guru dan media komputer yang telah digunakan, mengetahui cara melaksanakan proses pembelajaran dengan memanfaatkan media komputer, serta peka terhadap perkembangan teknologi dan informasi. Hal ini diperlukan agar guru mengetahui perannya sebagai fasilitator dan media sebagai stimulus dalam penyampaian materi, melaksanakan proses pembelajaran melalui media komputer dan memanfaatkan LCD proyektor untuk mempresentasian materi, memutarkan video dan mengakses internet untuk melakukan up date informasi dan mengupload materi pelajaran. Hambatan yang muncul dalam penggunaan media komputer yaitu hambatan dari segi teknis

Seperti ketersediaan listrik, ketersediaan koneksi internet, connector pada USB untuk menghubungkan flashdiks atau hardisk external pada laptop dan hambatan dari segi non-teknis seperti adanya urusan lain yang harus diselesaikan guru. Untuk mengatasi hambatan tersebut guru memiliki pengetahuan untuk melakukan troubleshooting yaitu pencarian atau pemeriksaan terhadap sumber masalah dan memperbaiki sumber masalah tersebut, kemudian mengganti metode pembelajaran dan mengupload materi pelajaran di website pribadi (blog) agar semua siswa bisa mengakses materi tersebut melalui jaringan internet dimanapun dan kapanpun.

\subsection{Saran}

Dalam hal ini kami akan memberikan saran-saran yang bersifat membangun yang diharapkan akan berguna bagi Sekolah antara lain:

1. Guru diharapkan bisa lebih pro aktif, kreatif dan inovatif dalam menyusun media pembelajaran berbasis teknologi informasi dan komunikasi dengan memanfaatkan laptop dan LCD Proyektor sebagai media pembantu sehingga tercipta materi pembelajaran yang berkualitas dan efisien.
2. Untuk pemanfaatan komputer sebagai media pembelajaran, diharapkan guru bisa memadukan unsur teks, video, gambar, suara, interaktif dan animasi kedalam satu wadah kemasan dalam bentuk CD Interaktif yang bisa membuat para siswa dapat belajar dimana saja dan kapan saja.

\section{DAFTAR PUSTAKA}

Arkün, S. \& Akkoyunlu, B. 2008. A Study on the Development Process of a Multimedia Learning Environment According to the ADDIE Model and Students' Opinions of the Multimedia Learning Environment. Interactive Educational Multimedia University of Barcelona, (17). (Online), (h ttp://w w w w. $\mathrm{r}$ ac o.ca t/inde x.php/iem/article/viewFile/205357/27389 5), diakses 8Maret 2017

Arsyad, Azhar. 2014. Media Pembelajaran. Jakarta: Raja Grafindo Persada

Heinich, R., et.al. 2005. Instructional Media and Technology for Learning. (8th ed). Englewood Cliffts New Jersey: PrenticeHall

Heinich, R., et.al. 2005. Instructional Media and Technology for Learning. (8th ed). Englewood Cliffts New Jersey: PrenticeHall

Jamil, Suprihatiningrum. 2013. Strategi Pembelajaran Teori \& Aplikasi. Jogjakarta: Ar-Ruzz Media

Mishra, S. \& Ramesh, C. Sharma. 2005. Interactive Multimedia in Education and Training. United States of America: Idea Group Publishing (an imprint of Idea Group Inc.

Dikutip dari http://bumipanritakitta. b $10 \mathrm{~g} \mathrm{~s} \mathrm{p} \mathrm{o} \mathrm{t.} \mathrm{c} \mathrm{o.} \mathrm{i} \mathrm{d} \mathrm{/} 2013 / 06 /$ pemanfaatanteknologi-dalam-pendidikan. Html yang diakses pada tanggal 13 september 2015.

Dikutip dari http://rachmatfatahillah. b 1 o g s p o t. c o. i d / $2014 / 04 /$ pengembanganpem-belajar an-paiberbasis.html yang diakses pada tanggal 13 september 2015.

Dikutip dari http://stitattaqwa. b 1 og s p ot. c o m/2011/07/pemanfaa tankomput erun tuk - pembelajaran. html. 
Adlin, SE., MM., ANALISIS KEMAMPUAN GURU DALAM MEMANFAATKAN MEDIA BERBASIS KOMPUTER PADA PEMBELAJARAN DI SEKOLAH DASAR

Yang diakses pada tanggal 22 Oktober 2015.

Dikutip dari http://www.dosenpendidikan. c om/15- dampak -nega tif- dan-positif t ek nolog i-inf or masi- dalam-bidangpendidikan/ yang diakses pada tanggal 13 September 2015. 